\title{
PROCEEDINGS
}

\author{
OF THE \\ Prebistoric Society \\ OF
}

\section{EAS'T ANGLIA}

For 1912-13.

VOL. I.-PART III.

(Edited by W. G. Clarke, Hon. Secretary).

LONDON :

H. K. LEWIS, 136, Gower Street.

1913. 